\title{
ORIGINALS
}

\section{Long Term Production of Insulin by Adult Rat Pancreas In Vitro}

\author{
Laris-Erik Jönsson, Jan Pont Én and Jan Thorext
}

Department of Pathology and Laboratory of Cell Biology, University of Uppsala, Uppsala, Sweden

Received March 1, 1966

Summary. Adult-rat islets of Langerhans were grown in organ culture for a period of one month. Prior to explantation exocrine parenchyma was made atrophic by ligation of the pancreatic duct. Insulin was determined. by immunoassay. The fluid phase was Eagle's medium with $10 \%$ calf serum. The gas phase was either $5 \% \mathrm{CO}_{2}$ in air or $5 \% \mathrm{CO}_{2}$ in oxygen. With $\mathrm{CO}_{2} /$ air small amounts of insulin averaging about $40 \mu \mathrm{U} / \mathrm{ml}$ wore found in the medium during the experimental period. With $\mathrm{CO}_{2}$ /oxygen the average concentration after 30 days was $70 \mu \mathrm{U} / \mathrm{ml}$ which was not significantly different from the starting value. Around day 15 a peak was reached with an average of $160 \mu \mathrm{U}$ of insulin per ml medium. - In $\mathrm{CO}_{2} /$ oxygen, medium had to be changed daily otherwise the islets succumbed rapidly in vitro. - Moderate degranulation of $\beta$-cells was found in $\mathrm{CO}_{2} /$ air already on day 1 and remained approximately unchanged until day 30 . In $\mathrm{CO}_{2}$ oxygen, degranulation did not generally start until $4-7$ days after explantation and cells with normal granularity persisted until day 30. - Degenerative changes such as fuzzy cell borders, pyknotic nuclei and decreased stainability were already seen in the $\mathrm{CO}_{2}$ /oxygen and the $\mathrm{CO}_{2} /$ air group on the first day after explantation. These alterations were more pronounced in the latter group where the degeneration caused a loss of many islets during the first 4 days. After this a more stable state was reached where remaining islets showed only slight degenerative changes. In $\mathrm{CO}_{2}$ /oxygen the degenerative changes were in general slight during the entire experimental period leading to loss of comparatively few islets.

Production d'insuline à long terme du pancréas de rat adulte in vitro.

Résumé. Des cultures d'organe d'îlots de Langerhans de rats adultes ont été maintenues pendant des périodes d'un mois. Avant leur explantation lo parenchyme exocrine était devenu atrophique à la suite de la ligature du canal de Wirsung. L'insuline a été mesurée par la méthode immunologique. Le milieu de culture était celui d'Eagle avec $10 \%$ de sérum de veau. La phase gazeuse était $5 \%$ de $\mathrm{CO}_{2}$ dans de l'air ou dans de l'oxygène. Avec le $\mathrm{CO}_{2}$ dans de l'air, les quantités d'insuline trouvées dans le milieu ont été en moyenne de $40 \mu \mathrm{U} / \mathrm{ml}$. En présence de $\mathrm{CO}_{2}$ et oxygène la concentration moyenne dans le milieu après 30 jours était de $70 \mu \mathrm{U} / \mathrm{ml}$ et ne différait pas significativement de la valeur au départ. Vers lo 15 ème jour un maximum était atteint avec, en moyenne, $160 \mu \mathrm{J} / \mathrm{ml}$ de liquide. En présence de $\mathrm{CO}_{2}$ et oxygène, le milieu de culture doit être changé quotidiennement sans quoi les îlots succombent rapidement in vitro. - Une dégranulation modérée des cellules $\beta$ a été observée dès le premier jour de l'incubation et s'est maintenue jusqu'au 30ème jour en présence de $\mathrm{CO}_{2}$ et d'air. En présence de $\mathrm{CO}_{2}$ et oxygène cette dégranulation n'a débuté que vers 4 à 7 jours après l'explantation et un certain nombre de cellules normalement granulées ont persisté jusqu'au 30ème jour. - Des indices morphologiques de dégénéra. tion ont été observés tant en présence de $\mathrm{CO}_{2}$ et oxygène qu'en présence de $\mathrm{CO}_{2}$ et air dès le premier jour après l'explantation. Les indices de dégénérescence étaient l'aspect flou des limites cellulaires, la pycnose de certains noyaux. et une diminution de la coloration. Ces altérations étaient, plus prononcées pour le groupe d'incubation en présence de $\mathrm{CO}_{2}$ et air et de nombreux îlots ont disparu par dégénération durant les 4 premiers jours. Par la suite la préparation est devenue plus stable et les signes de dégénérescence des îlots restant ont été modestes. En présence de $\mathrm{CO}_{2}$ et oxygène les modifications dégénératives ont été bien moindres pendant toute la période expérimentale et peu d'îlots seulement ont été perdus.

Langanhaltende Insulinbildung durch Pankreasgewebe ausgewachsener Ratten in vitro.

Zusammenfassung. Langerhans'sche Inseln ausgewachsener Ratten wurden einen Monat lang in Organkulturen gezüchtet. Vor dem Ansetzen der Kulturen war das exokrine Parenchym durch Ligatur des Ductus pancreaticus zur Atrophie gebracht worden. Das Insulin wurde mit der immunologischen Methode bestimmt. Eagle's Medium mit 10\% Kälberserum diente als flüssige Phase, entweder $5 \% \mathrm{CO}_{2}$ in Luft oder $5 \% \mathrm{CO}_{2}$ in Sauerstoff als Gasphase. Mit $\mathrm{CO}_{2} /$ Luft wurden im Medium während der Versuchsdauer kleine Insulinmengen von durchschnitt. lich etwa $40 \mu \mathrm{E} / \mathrm{ml}$ gemessen. $\mathrm{Mit} \mathrm{CO}_{2} /$ Sauerstoff war die durchschnittliche Konzentration nach 30 Tagen $70 \mu \mathrm{E} / \mathrm{ml}$; dieser Wert unterschied sich nicht signifikant vom Ausgangswert. Etwa nach 15 Tagen wurde ein Maximum mit einem durchschnittlichen Wert von $160 \mu \mathrm{E}$ Insulin pro ml Medium erreicht. In $\mathrm{CO}_{2}$ /Sauerstoff mußte das Medium täglich erneuert werden, da sonst die Inseln in vitro rasch zugrunde gingen. - In $\mathrm{CO}_{2} / \mathrm{Luft}$ trat schon am ersten Tag eine mäßige Degranulation der $\beta$-Zellen ein, die fast unverändert bis zum 30. Tag bestehen blieb. In $\mathrm{CO}_{2} /$ Sauerstoff $\mathrm{kam}$ es im allgemeinen erst nach $4-7$ Tagen nach der Gewebsauspflanzung zu einer Degranulation, und Zellen mit normaler Granulierung blieben bis zu 30 Tagen bestehen. - Degenerative Veränderungen wie aufgefaserte Zellränder, pyknotische Kerne und herabgesetzte Färbbarkeit wurden in $\mathrm{CO}_{2} /$ Sauerstoff und $\mathrm{CO}_{2} /$ Luft bereits am ersten Tag nach der Auspflanzung beobachtet. Diese Veränderungen waren in der letzteren Gruppe stär. ker ausgeprägt, bei der die Degeneration den Verlust vieler Zellen während der ersten 4 Tage verursachte. Danach wurde ein stabileres Stadium erreicht, wobei die erhaltenen Inseln nur leichte degenerative Veränderungen zeigten. In $\mathrm{CO}_{2} /$ Sauerstoff waren während des gesamten Versuches die generativen Veränderungen im allgemeinen leicht und führten vergleichsweise nur zum Verlust weniger Inseln. 
Studies of endocrine pancreas in tissue culture have almost entirely been limited to fetal organs. Insulinlike activity has been detected in the culture fluids even after rather long periods of cultivation [1]. MURRer [9], in a recent quantitative study, showed that fetal rat islets synthesized insulin for at least 10 days after explantation.

Experiments with adult islets should give additional information since embryonic tissue may not properly reflect the conditions in the fully differentiated organ. Work with adult pancreas is however rendered difficult by the presence of enzyme-liberating, exocrine parenchyma, which exerts a destructive effect in isolated pieces. Experiments in vivo with transplants to the anterior chamber of the eye have shown that this difficulty can be overcome if exocrine parenchyma is selectively destroyed by duct ligation before transplantation [5].

The present communication describes a method whereby islets from adult, duct-ligated rats can be maintained in organ culture for at least 30 days, apparently without losing their morphologic or functional integrity. No studies on long-term insulin production by an adult organ in vitro seem to have been published previously. Morphologically intact islets obtained from adult guinea pig and freed of exocrine parenchyma by collagenase treatment, have been found to survive at least 14 days of cultivation in vitro [8].

\section{Material and methods}

Animals. Four month old Wistar rats of both sexes were used.

Ligation of the pancreatic duct. Atrophy of the lienal part of the exocrine parenchyma was achieved by applying a ligature between the middle and lienal third of the organ - "partial ligature" [4].

Tissue culture. Organ cultures. Pieces of pancreas were aseptically removed 30 days after the pancreatic duct had been ligated. At this stage the organ consists of islets of LANGERHANS embedded in vascular connective tissue, where ducts but no exocrine cells remain [4].

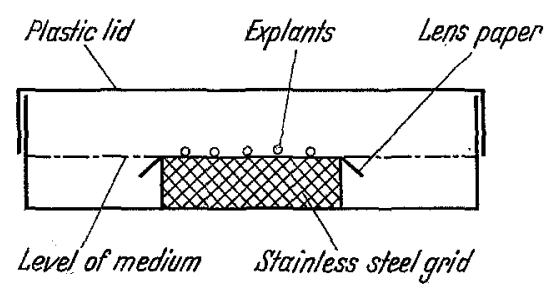

Fig. 1. Construction of the organ culture vessel

The excised tissue was divided with a scalpel into small pieces measuring about one $\mathrm{mm}^{3}$. Within one minute of removal, the explants were introduced into organ cultures (Fig. 1) set up essentially according to JENSEN et al. [7]. Incubation was done at $37^{\circ} \mathrm{C}$ in a continuous flow of humidified gas, either $5 \% \mathrm{CO}_{2}$ in air or $5 \% \mathrm{CO}_{2}$ in oxygen.
Each culture was nourished by $5 \mathrm{ml}$ Eagle's minimal essential medium [13] with $10 \%$ calf serum, penicillin $(100 \mathrm{U} / \mathrm{ml})$ and streptomycin $(50 \mu \mathrm{g} / \mathrm{ml})$. Phenol red was omitted because of its interference with the colorimetric determinations of glucose. The $\mathrm{pH}$ was indirectly checked by keeping medium with indicator. in the same box as the organ cultures. Removed medium was stored at $-18^{\circ} \mathrm{C}$ and later assayed for insulin and glucose. When more than one rat was used for a particular experiment, pooled tissue from all animals was randomly distributed among the individual culture vessels. The time interval between excision of the pancreas and start of incubation of the explants was less than 30 minutes.

Monolayer cultures. The human diploid cell strain WI-38 [2] was used in passage 20-30. Media and conditions of culture were the same as for the organ cultures.

Histological methods. Pieces were carefully removed from the organ cultures, fixed in Bouin's solution, embedded in paraffin, cut into serial sections and stained with paraldehydefuchsin-Ponceaufuchsin.

Glucose determinations. The glucose oxidase method as described by HJ ELM and DEVERDIER was followed [3]

Insulin determinations. Insulin was immunoassayed essentially according to YALOW and BersoN [14]. Antiserum was produced in guinea-pigs immunized by monthly injections of recrystallized beef insulin in FreUND's incomplete adjurant. Antiserum was collected 2 weeks after last injection. Insulin-131I was prepared with a slight modification [14] of the method of HuNTER and GREenwood [6] for labeling growth hormone.

$50 \mu \mathrm{l}$ of the culture medium sample together with $1 \mu \mathrm{U}$ of insulin- ${ }^{131} \mathbf{I}$ and insulin antiserum (dilution $1: 80000$ ) was incubated at $4^{\circ} \mathrm{C}$ for 3 days in a total volume of $0.5 \mathrm{ml}$. All dilutions were made in $0.1 \mathrm{M}$ Veronal buffer, $\mathrm{pH} 8.6$, containing $0.125 \%$ human serum albumin. After incubation bound and free insulin were separated by paper chromatography in $0.1 \mathrm{M}$ Veronal buffer after addition of $50 \mu \mathrm{l}$ of human plasma. The strips were cut into two parts and the radioactivity of the two fractions measured in a wellcounter.

A standard curve based on analysis of $1-12 \mu \mathrm{U}$ of Novo recrystallized human insulin was always included. All samples were assayed in duplicate. The standard error of the mean was less than $\pm 4 \mu \mathrm{U} / \mathrm{ml}$.

\section{Experimental}

1. Adult rat pancreas incubated in air- $\mathrm{CO}_{2}$. Six organ cultures were incubated in $5 \% \mathrm{CO}_{2}$ and $95 \%$ air. Medium was changed twice a week. Pieces were removed for histological examination 1, 2, 4, 7, 15, and 30 days after explantation. A few viable islets were found on all these occasions. However in most there were rather severe degenerative changes already on day 1 , which did not diminish with time. 
2. Effect of high oxygen concentrations on adult rat pancreas. These experiments were motivated by the results of MURREL [9] who could demonstrate synthesis of insulin and cell differentiation of fetal rat tissue incubated in the presence of a high oxygen concentration. Organ cultures were incubated in $5 \% \mathrm{CO}_{2} /$ $95 \% \quad \mathrm{O}_{2}$. Medium was changed twice a week. Pieces were removed for histological examination $1,2,4,7,15$, and 30 days after explantation. It was found that extensive necrosis had already occurred by day 2 and that no recovery took place with longer periods of incubation.

Repeated determinations showed a rapid consumption of glucose (Fig. 2). Three to four days after

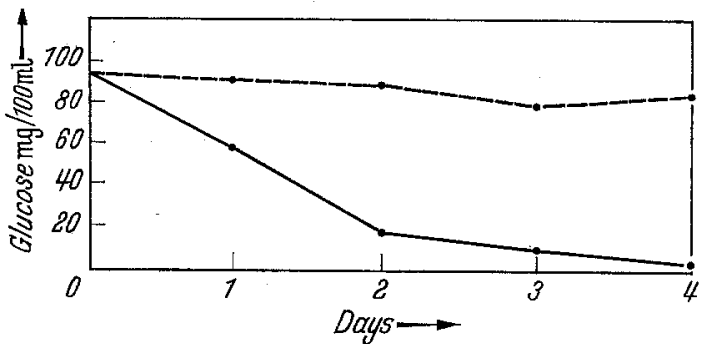

Fig. 2. Comparison of glucose-consumption in cultures containing islet tissue (uninterrupted line) and control cultures with no tissue (dotted line). Gas phase: $5 \% \mathrm{CO}_{2} / 95 \% \mathrm{O}_{2}$

explantation and before medium was changed virtually no glucose remained. Since this depletion might be responsible for extensive necrosis, the effect of adding extra glucose was studied. Pilot experiments were carried out with human fibroblasts in monolayer cultures.

3. Effect of high oxygen concentrations on fibroblast monolayers. WI-38 cells were kept as monolayers without subcultivation under conditions listed in table 1. Four Petri dishes were used in each group. The

Table 1. Viability of human diploid fibroblasts (strain WI38) under different conditions in vitro. All cultures kept in Eagle's medium (13) with $10 \%$ calf serum

\begin{tabular}{lllll}
\hline & & eonditions of culture & & \\
$\begin{array}{l}\text { group } \\
\text { no. }\end{array}$ & gas phase & medium changes & $\begin{array}{l}\text { extra } \\
\text { glucose } \\
\text { added }\end{array}$ & $\begin{array}{l}\text { survival } \\
\text { time } \\
\text { (days) }\end{array}$ \\
\hline 1 & $5 \% \mathrm{CO}_{2}$ in air & every 3rd day & no & $>20$ \\
2 & $5 \% \mathrm{CO}_{2}$ in $\mathrm{O}_{2}$ & every 3rd day & no & 5 \\
3 & $5 \% \mathrm{CO}_{2}$ in $\mathrm{O}_{2}$ & $\begin{array}{l}\text { every 3rd day } \\
\text { daily** }\end{array}$ & $\begin{array}{l}\text { yes* } \\
\text { yes* }\end{array}$ & $>20$ \\
4 & $5 \% \mathrm{CO}_{2}$ in $\mathrm{O}_{2}$ & daly & &
\end{tabular}

* addition of $2.5 \mathrm{mg}$ daily

** half of the volume of medium $(2.5 \mathrm{ml})$ was replaced by $2.5 \mathrm{ml}$ of fresh medium at intervals of 24 hours.

*** interval between start on experiment and detachment and death of at least $90 \%$ of the cells.

observation period was 20 days. Toxic effects resulting in cell death were noted in groups 2 and 3 , whereas the other two groups were unaffected within the experimental period (Table 1). The toxic effect of oxygen in group 2 was comparable with that in the rat organ cultures (see above). This is in accordance with previous observations on the effect of high oxygen concentrations on animal cells $[2,10,12,13]$. It was possibly partially reversed by addition of glucose in amounts sufficient to compensate for the rapid consumption (group 3) as shown by a small lengthening of the survival of the cultures. If, however, complete medium was added daily (group 4), the fibroblasts showed no degenerative changes and still had a viable appearance after 20 days in the high oxygen atmosphere.

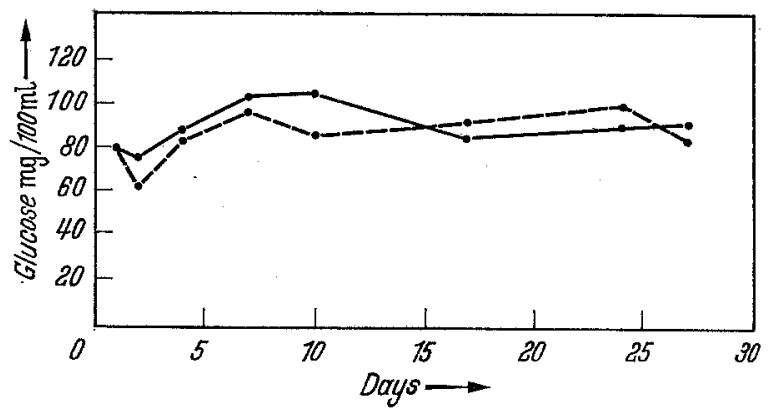

Fig. 3. The mean values of glucose concentration in the medium of islet tissue explants at different intervals. Medium was changed daily Uninterrupted jine denotes $5 \% \mathrm{CO}_{2} / 95 \% \mathrm{O}_{2}$ Interrupted line denotes $5 \% \mathrm{CO}_{2} / 95 \%$ air

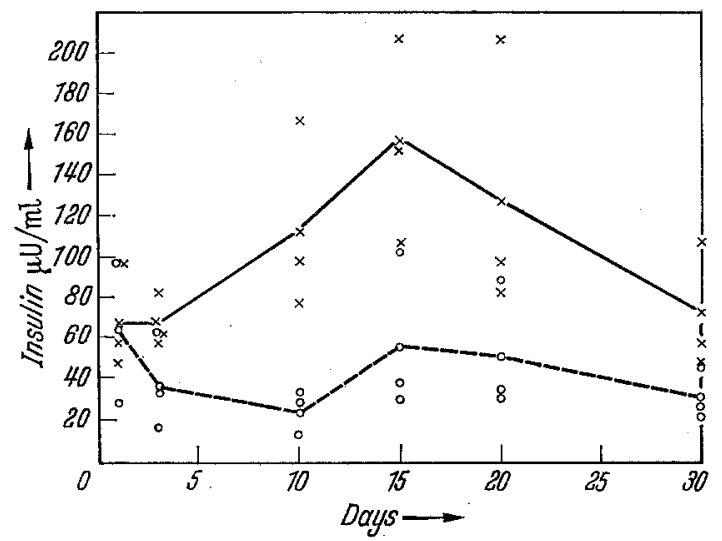

Fig. 4. Concentration of insulin in the medium of organ cultures of adult rat islet tissue during 30 days after explantation. Crosses and unintermuted line denote $5 \% \mathrm{CO}_{2} / 95 \% \mathrm{O}_{2}$ Circles and interrupted line denote $5 \% \mathrm{CO}_{2} / 95 \%$ air

4. Cultivation of rat islet tissue with addition of glucose and daily changes of medium. Pancreatic tissue from rats was pooled and divided into two experimental groups each consisting of three cultures. Half of the medium $(2.5 \mathrm{ml})$ was removed daily and substituted with the same amount of fresh medium. In addition $0.3 \mathrm{ml}$ of $30 \%$ glucose was added at intervals of 24 hours. One group was incubated in $5 \% \mathrm{CO}_{2}$ in air and the other in $5 \% \mathrm{CO}_{2}$ in oxygen. The experiment was terminated on day 30 when all the explants were fixed and processed for histological examination.

The results of the glucose determinations are given in Fig. 3. It is seen that a stable concentration of about $90 \mathrm{mg} / 100 \mathrm{ml}$ was maintained throughout the experiment. The insulin determinations are plotted in Fig. 4. It is seen that the values for the first day did 
not differ significantly between the two groups. Samples from day $3,10,15,20$, and 30 showed higher average levels of insulin in the oxygen group. There was a suggestion of changes in the insulin concentration with time. In the high-oxygen group, peak values were reached around day $15-20$, whereas no similar peak could be discerned in the "air group". Both groups seemed to show a decreasing amount of insulin in the medium towards the end of the experiment, i.e. the values for day 30 were consistently lower than on day 20.

Table 2. Histological observations on islet tissue kept in $\mathrm{CO}_{2} /$ oxygen or $\mathrm{CO}_{2} /$ air with daily changes of medium

\begin{tabular}{|c|c|c|c|c|c|}
\hline \multirow{2}{*}{$\begin{array}{l}\text { Days } \\
\text { after } \\
\text { explanta- } \\
\text { tion }\end{array}$} & \multirow{2}{*}{$\begin{array}{l}\text { Culture } \\
\text { no. }\end{array}$} & \multicolumn{2}{|c|}{$\begin{array}{l}\text { Degranulation of } \\
\text { beta-cells* }\end{array}$} & \multicolumn{2}{|c|}{$\begin{array}{l}\text { Degree of islet } \\
\text { degeneration** }\end{array}$} \\
\hline & & $\mathrm{CO}_{2} / \mathrm{O}_{2}$ & $\mathrm{CO}_{2} / \mathrm{air}$ & $\mathrm{CO}_{2} / \mathrm{O}_{2}$ & $\mathrm{CO}_{2} /$ air \\
\hline \multirow{4}{*}{1} & 1 & 0 & I & 0 & ++ \\
\hline & 2 & 0 & I & + & $+t$ \\
\hline & 3 & 0 & I & + & ++ \\
\hline & 4 & $I$ & I & + & ++ \\
\hline \multirow{4}{*}{2} & 1 & 0 & $\mathrm{I}$ & + & ++ \\
\hline & 2 & 0 & I & + & ++ \\
\hline & 3 & 0 & I & + & ++ \\
\hline & 4 & 0 & II & + & +1 \\
\hline \multirow{4}{*}{4} & 1 & I & I & ++ & +++ \\
\hline & 2 & $I$ & I & $+t$ & ++ \\
\hline & 3 & I & I & + & ++ \\
\hline & 4 & I & I & + & ++ \\
\hline \multirow{4}{*}{7} & 1 & 0 & I & + & + \\
\hline & 2 & 0 & I & + & + \\
\hline & 3 & 0 & $I$ & ++ & + \\
\hline & 4 & $I$ & I & ++ & + \\
\hline \multirow{4}{*}{30} & 1 & 0 & I & + & + \\
\hline & 2 & 0 & I & + & + \\
\hline & 3 & 0 & I & + & $+t$ \\
\hline & 4 & 0 & I & + & + \\
\hline
\end{tabular}

* Assessment of degranulation

0 Normal content and appearance of granules

I A few small areas with hydropic cells or cells showing some loss of granules. Large majority of cells still normal.

II More than half of the cells hydropic with remaining cells showing some loss of granules. No cells with normal granularity persist.

** Proportion of islets with degenerative cell changes (loss of stainability, fuzzy cell borders, pyknotic nuclei).

$$
\begin{array}{lr}
0 \text { none } & ++1 / 4-1 / 2 \\
+ \text { less than } 1 / 4 & +++1 / 2-3 / 4
\end{array}
$$

Histological observations are summarized in table 2. It is seen that alterations interpreted as degenerative occurred even after the culture conditions were improved by the introduction of a gas phase rich in oxygen, daily medium changes and substitution of consumed glucose. They were, however, slight and did not seem to progress significantly with time. They were more pronounced in the groups where a $\mathrm{CO}_{2}$-air mixture had been used instead of $\mathrm{CO}_{2}$-oxygen. After 30 days the changes were rather inconspicuous, most often graded as "one plus" in both groups. A feature not shown in the table was an apparent decrease of the number of detectable islets with time. The exocrine duct epithelium, the vessel walls and the connective tissue showed slight degenerative changes in both groups with no certain differences between the "oxygen" and the "air" group.

A rather pronounced degranulation of beta cells occurred in the group incubated in $\mathrm{CO}_{2}$-air (Table 2). This was already apparent 24 hours after explantation and did not seem to increase further with time. A similar degranulation has been described in adult guinea pig islets in organ culture [8]. The degree of degranulation was less pronounced in the high-oxygen atmosphere, and only one culture showed any deviation from normal before day 4 after explantation. $\alpha$-cells were seen in both the "air" and the "oxygen" group.

A notable difference between tissues kept in high and low concentrations of oxygen concerned the migration of fibroblasts. In the cultures kept in $\mathrm{CO}_{2}-$ air, fibroblasts invaded the meshwork of fibers of the supporting lens paper. Some attached to the bottom of the plastic Petri dish and eventually formed monolayers. In the presence of $95 \%$ oxygen, flbroblasts only migrated to a very slight extent and no attachment of cells to the bottom of the culture vessel took place.

\section{Discussion}

Two factors - high oxygen concentration and daily changes of medium - were found to be essential for the long term function to adult rat islet tissue in vitro. The dependence of endocrine tissue on adequate oxygenation has been previously demonstrated repeatedly and was also found to be essential for the differentiation of fetal rat islets [9].

An increased supply of oxygen was, however, toxic if no adjustments were made of the composition of the medium. This "oxygen toxicity" has been noted previously $[2,10,12,13]$. It seemed to affect undifferentiated fibroblasts as well as the highly differentiated islet organ in the present experiments. The toxicity could be prevented by daily renewal of $50 \%$ of the medium. Whether this involves the removal of toxic products, replenishment of essential, rapidly consumed metabolites or both is not known.

The degenerative changes observed even in cultures exposed to frequent changes of medium and high concentrations of oxygen are difficult to interpret. Since they did not progress significantly with time beyond the fourth day after explantation, they may reflect adverse influences connected with the explantation procedure and initial adaptation to life in vitro rather than tissue culture conditions per se. The prolonged persistence of high levels of insulin in the medium supports this contention. How far the insulin found in the medium represented release of preformed hormone or actual synthesis in vitro was not determined.

The technique described permits adult pancreatic islet tissue to be cultivated for a long period in vitro 
and to retain its capacity to produce insulin. Future use of the method should make it possible to study regulatory mechanisms for insulin production at a level where most of the shortcomings of an in vivo approach are avoided.

\section{References}

[1] Concson, R.E.: Functional and histological observations on islet tissue grown in vitro. Anat. Rec. 124, 484 (1956).

[2] HAYFLICK, L.: The limited in vitro lifetime of human diploid cell strains. Exp. Cell Res. 37, 614-636 (1965).

[3] HJELM, M., and C.H.DE VERDIER: A methodological study of the enzymatic determination of glucose in blood. Scand. J. clin. Lab. Invest. 4, 15 (1963).

[4] Hulteuist, G.T., and L.E. Jönsson: Ligation of the pancreatic duct in rats. Acta Soc. Med. upsaliensis 1-2, 82-88 (1965).

[5] - , and J. ThoRELL: A method for isolating islets of Langerhans by transplantation. Acta Soc. Med. upsaliensis 69, 291-303 (1964).

[6] Hunter, W.M., and F.C. Greenwood: Preparation of iodine-131 labeled human growth hormone of high specific activity. Nature (Lond.) 194, 495 (1962).

[7] Jensen, F.C., R.B.L. Gwatkin and I.D. BIGGERs: A simple organ culture method which allows simultaneous isolation of specific types of cells. Exp. Cell Res. 34, $440-447$ (1964).

[8] Moskalewski, S.: Isolation and culture of the islets of Langerhans of the guinea pig. Gen. Comp. Enocrinol. 5, 342-353 (1965).

[9] MurReu, L.R.: Endocrine pancreas of the fetal rat in organ culture: Culture methods, some aspects at histogenesis, insulin synthesis, and release and the incorporation, of tritiated leucine into tissue protein fractions. University of Minnesota, Ph. D. Diss., No. 64-9499, Univ. Microfilms, Inc., Ann Arbor, Michigan. (1964).

[10] Page, D.M., I.R. Thompson and W.A. van Camp: Effects of oxygen on growth in several established cell lines. J. nat. Cancer Inst. 28, 897-907 (1962).

[11] ThoreLL J. I.: Insulin antibodies in pregnant guinea pigs and in their offspring. Acta Endocr. (Kbh) $52,255-267$ (1966).

[12] Trowell, O.A.: The culture of mature organs in a synthetic medium. Exp. Cell Res. 16, 118-147 (1959).

[13] WIIIMMER, E.N., et al. Cells and tissues in culture. Methods, Biology and Physiology I, II. Acad. Press. London-New York (1965).

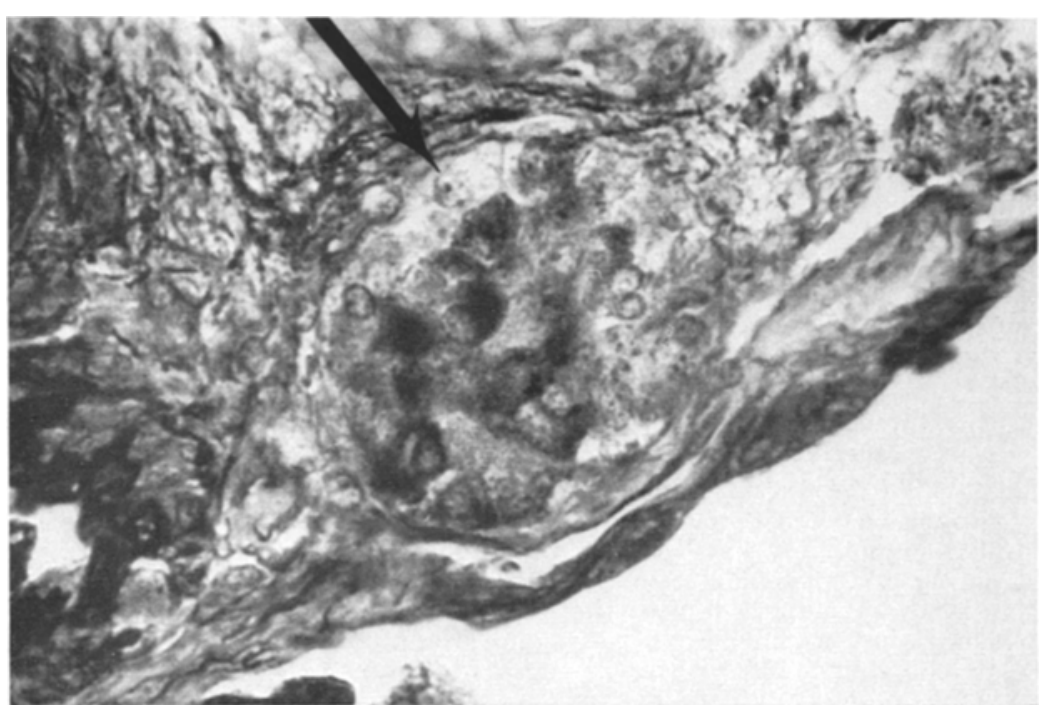

Fig. 5. Islet of Langerhans in 6-day-old explant kept in $5 \% \mathrm{CO}_{2} / 95 \% \mathrm{O}_{2}$ atmosphere with daily changes of medium supplemented with glucose. $\alpha$-cells are present at the periphery of the islet (arrow)

Paraldehydefuchsin - Ponceaufuchsin. $\times 720$

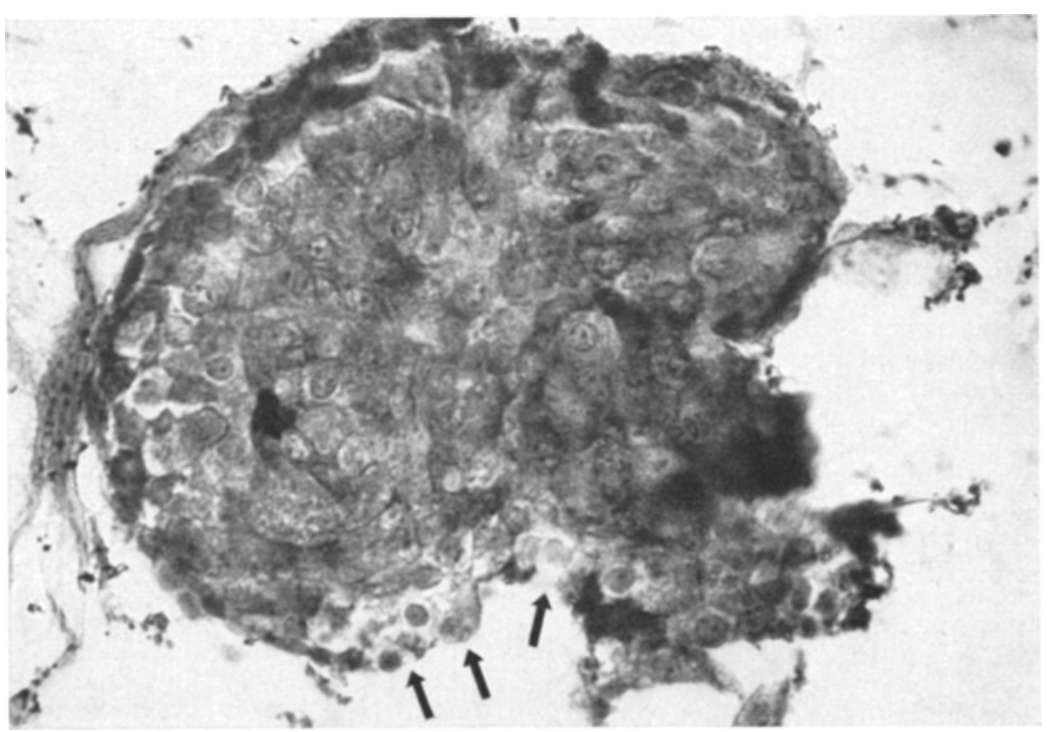

Fig. 6. Islet-tissue in 30-day-old explant keptin $5 \% \quad \mathrm{CO}_{2} / 95 \% \quad \mathrm{O}_{2}$ with daily changes of medium supplemented with glucose. Note presence of $\alpha$-cells (arrows) Paraldehydefuchsin - Poncearufuchsin. $\times 720$

[14] YALOW, R.S., and S.A. Berson: Immunoassay of endogenous plasma insulin in man. J. clin. Invest. $39,1157-1175$ (1960).

Dr. LaRs-Erik Jönsson

Department of Pathology

and Laboratory of Cell. Biology,

University of Uppsala,

Uppsala, Sweden 